\section{Mineral Composition of Kentucky Bluegrass under Recycled Water Irrigation on Golf Courses}

\author{
Yuhung Lin and Yaling Qian ${ }^{1}$ \\ Department of Horticulture and Landscape Architecture, Colorado State \\ University, Fort Collins, CO 80523
}

Additional index words. turfgrass, water reuse, salinity, sodium absorption ratio, recycled water, irrigation

\begin{abstract}
Golf courses in the western United States increasingly are being irrigated with recycled water. Research was conducted on eight golf courses in a semiarid region, including three courses with recycled water irrigation for 10 years, three courses with recycled water irrigation for 18 to 26 years, and two courses with surface water for irrigation for 15 and 18 years. Turf quality of kentucky bluegrass (Poa pratensis) (KBG), the most widely used turfgrass species in the United States, was evaluated on 25 roughs from the aforementioned golf courses. Concurrently, KBG shoot samples and soil samples from these sites were collected. Shoots of KBG were analyzed for mineral concentrations, including sodium (Na), calcium (Ca), magnesium (Mg), potassium (K), chlorine $(\mathrm{Cl})$, boron $(\mathrm{B})$, sulfur $(\mathrm{S})$, phosphorus $(\mathrm{P})$, manganese, iron, zinc, copper, and molybdenum. Electrical conductivity (EC) and sodium absorption ratio (SAR) of soil saturated paste were determined. Recycled water irrigation for 10 and $>18$ years increased clipping $\mathrm{Na}$ by 4.3 and 9.9 times and $\mathrm{Cl}$ by 1.5 and 1.3 times, respectively. Compared with surface water irrigation, B concentration in KBG shoots increased by 3.5 times and $K$ concentration reduced by $16 \%$ on sites with recycled water irrigation for $>18$ years. Multiple regression analysis was conducted to identify the relationships between mineral concentration in shoots and turf quality. There was a negative linear relationship between turf quality and Na concentration in the shoots $\left(R^{2}=0.65\right)$. Soil SAR in 0 to $20 \mathrm{~cm}$ depth was highly associated with KBG shoot $\mathrm{Na}$, as documented by a logarithmic regression of $R^{2}=0.70$. Stepwise regression indicated that $\mathrm{Na}$ accumulation in the shoots was the leading plant variable causing the decline of turf quality under recycled water irrigation. Therefore, it is reasonable to believe that water treatment and management practices that can reduce soil SAR and Na concentration in KBG shoots would improve turf quality and plant health.
\end{abstract}

Water deficiency is common in the western United States, such as California, Nevada, Arizona, Utah, Colorado, and New Mexico, where climate is arid and semiarid. Approximately $30 \%$ to $50 \%$ of the potable water is used for outdoor landscape irrigation in these western states (Maupin et al., 2014). Water scarcity and population expansion are the impetuses for many cities and water districts to search for alternative strategies to promote fresh water conservation. One strategy is using treated wastewater (recycled water) for landscape irrigation. Golf courses are the leading urban landscape users of recycled water.

The total area of golf courses in the United States was 608,732 ha in 2007 . It is estimated that during 2003 to $2005,80 \%$ of maintained turfgrass on 18-hole golf courses had been irrigated annually with 285 million cubic meters of water (Golf Course Superintendents Association of America, 2009). Recycled water irrigation can significantly reduce fresh

Received for publication 10 Oct. 2018. Accepted for publication 7 Dec. 2018.

1Corresponding author. E-mail: yaling.qian@colostate. edu. vaginatum), and st. augustinegrass (Stenotaphrum secundatum) salinity tolerance was strongly associated with $\mathrm{Na}^{+}$and $\mathrm{Cl}^{-}$exclusion in the shoot. Salt tolerance also highly depended on lower ion concentrations retained in the shoot tissue (Gorham et al., 1985; Marcum and Murdoch, 1990). Alshammary et al. (2004) examined salinity tolerance of KBG, tall fescue (Lolium arundinaceum), alkaligrass (Puccinellia distans), and saltgrass (Distichlis spicata) in a greenhouse experiment. KBG was the most sensitive to salinity treatment among these four species, based on criteria of turf quality, shoot and root dry weight, and root to shoot ratio. The more salt resistant species had less shoot $\mathrm{Na}^{+}$and $\mathrm{Cl}^{-}$ accumulation and a greater shoot $\mathrm{K}^{+} / \mathrm{Na}^{+}$ratio than the salt-sensitive grasses. Very limited research information is available regarding the degree of salt accumulation in turfgrass shoots when recycled water is used for irrigation. More research is needed to determine the relationships among soil salinity parameters, KBG turf quality, and shoot mineral concentrations.

The objectives of this research were 1) to evaluate turf quality and shoot mineral concentration of KBG grown on golf courses irrigated with recycled water for different years and 2) to determine the relationships among KBG turf quality, shoot mineral concentrations, and soil salinity parameters.

\section{Materials and Methods}

\section{Study sites}

Eight golf courses in the northern Colorado area were selected for the study. Among these courses, three had been irrigated with recycled wastewater for 10 years. We refer to golf courses in this group as "10-year recycled water irrigation golf courses." Another three golf courses had been irrigated with recycled wastewater for 18,24 , and 26 years, respectively. We refer to golf courses in this group as "pioneer recycled water irrigation golf courses." The other two courses irrigated with surface water in the region were selected for comparison. All of the eight courses have 18 holes. These courses were included because 1) all were within $35 \mathrm{~km}$ of premises; 2) the management practices, such as mowing height and frequency, were very similar; 3 ) turfgrass species grown on these courses were the same with all having KBG roughs; 4) all study sites were irrigated every other day during the growing season with turfgrass receiving $\approx 55$ to $75 \mathrm{~cm}$ of irrigation water annually; and 5) surface water irrigated courses were fertilized with $\approx 150 \mathrm{~kg} \cdot \mathrm{ha}^{-1}$ nitrogen $(\mathrm{N})$ annually, whereas recycled water irrigated golf courses were fertilized with $\approx 75$ to 100 $\mathrm{kg} \cdot \mathrm{ha}^{-1} \mathrm{~N}$ annually; this fertilization difference is to account for the amount $\mathrm{N}$ provided by recycled water. The main difference was irrigation water source or the duration of recycled water irrigation. The average water quality data are presented in Table 1. Most of the surface water came from melting snow of the Rocky Mountains and exhibited good 
quality; all surface water samples were classified as C1-S1, namely low in salinity and low in Na hazard (Richards, 1954). Although all collected recycled water samples were classified as C3-S1, i.e., high in salinity and low for $\mathrm{Na}$ hazard, recycled water $\mathrm{Na}$ content was 5.5 to 7.5 times greater than that in the surface water (Table 1).

The study sites were in a semiarid climate. The average annual precipitation is about $35 \mathrm{~cm}$.

May to August are the months with monthly precipitation typically exceeding $5 \mathrm{~cm}$. The reference evapotranspiration in northern Colorado ranges from 95 to $120 \mathrm{~cm}$ during the growing season (Clifford and Doesken, 2009).

\section{Data collection}

Three to four random holes from each golf course were chosen, and data on turf quality and soil and KBG shoot samples were collected from 11 holes in the " 10 -year recycled water irrigation golf courses." For the "pioneer recycled water irrigation golf courses," the total number of holes included for data collection was nine. Data also were collected from five holes of two golf courses that had been established at least 15 years ago and had been irrigated with surface fresh water since the course development. Over a 5-week period in late July to August, plant and soil samples were collected once for each site, and turf quality was evaluated concurrent with soil and plant sample collections.

Plant materials. We collected turf shoot samples on the roughs less than $2.5 \mathrm{~m}$ away from the sides of fairways. No apparent traffic injuries were present at the selected datacollection areas. Turfgrass was regularly mowed to 50 to $64 \mathrm{~mm}$. Three shoot samples from three $100-\mathrm{cm}^{2}$ randomly selected areas of each hole were collected using scissors cutting about $1 \mathrm{~cm}$ aboveground surface. Three samples were combined. All samples were sealed in zip-lock plastic bags and placed in a cooler for transportation to the laboratory.

Turf quality. Concurrent with shoot sample collection, turf quality for $\approx 5 \mathrm{~m}^{2}$ of the rough area surrounding the shoot sample collection spots was rated based on color, density, and uniformity, with a rating of 1 representing brown, thin, dead turf. A rating of 6 was considered minimum acceptable turf for golf course rough, and 9 was considered the best quality, with the appearance of dense, uniform turf with an emerald green color (Morris and Shearman, 2010).

Analysis of shoot mineral concentration. Turf shoots were rinsed with deionized water and dried in an oven at $70{ }^{\circ} \mathrm{C}$ for $24 \mathrm{~h}$. Afterward, the materials were ground in a Thomas Wiley Mill to pass through a screen with $425-\mu \mathrm{m}$ openings. About $1 \mathrm{~g}$ of screened and dried sample was weighed and ashed for $7 \mathrm{~h}$ at $500{ }^{\circ} \mathrm{C}$. Ash was dissolved in $10 \mathrm{~mL}$ of $1 \mathrm{~N} \mathrm{HCl}$ and diluted with deionized water. Solution aliquots were analyzed on inductively coupled plasma atomic emission spectrophotometry (Model 975 plasma Atomcomp; Thermo Jarrell Ash Corp., Franklin, MA). Chloride concentration was analyzed using

Table 1. Average water quality values of surface water (ditch water) and recycled water for the 10-year recycled water irrigation golf courses and the pioneer recycled water irrigation golf courses from advanced wastewater treatment plants.

\begin{tabular}{lccc}
\hline Water parameter & Surface water & $\begin{array}{c}\text { 10-yr recycled } \\
\text { water irrigation }\end{array}$ & $\begin{array}{c}\text { Pioneer recycled water } \\
\text { irrigation }(18-26 \text { yr })^{\mathrm{y}}\end{array}$ \\
\hline $\mathrm{pH}$ & 7.6 & 7.2 & 7.4 \\
$\mathrm{NH}_{4} \mathrm{~N}\left(\mathrm{mg} \cdot \mathrm{L}^{-1}\right)$ & $\mathrm{N} / \mathrm{A}$ & 0.25 & 0.75 \\
$\mathrm{NO}_{3} \mathrm{~N}\left(\mathrm{mg} \cdot \mathrm{L}^{-1}\right)$ & 0.42 & 11.8 & 4.0 \\
Total P & 0.10 & 0.15 & 0.35 \\
Total dissolved solids $\left(\mathrm{mg} \cdot \mathrm{L}^{-1}\right)$ & 132 & 613 & 638 \\
$\mathrm{EC}\left(\mathrm{dS} \cdot \mathrm{m}^{-1}\right)$ & 0.23 & 0.92 & 0.99 \\
$\mathrm{Ca}\left(\mathrm{mg} \cdot \mathrm{L}^{-1}\right)$ & 16 & 50 & 67 \\
$\mathrm{Mg}\left(\mathrm{mg} \cdot \mathrm{L}^{-1}\right)$ & 5 & 12 & 12 \\
$\mathrm{Na}\left(\mathrm{mg} \cdot \mathrm{L}^{-1}\right)$ & 15 & 121 & 101 \\
$\mathrm{Cl}\left(\mathrm{mg} \cdot \mathrm{L}^{-1}\right)$ & 18 & 103 & 120 \\
$\mathrm{Bicarbonate}\left(\mathrm{mg} \cdot \mathrm{L}^{-1}\right)$ & 53 & 92 & 125 \\
$\mathrm{Sulfate}\left(\mathrm{mg} \cdot \mathrm{L}^{-1}\right)$ & 25 & 142 & 182 \\
$\mathrm{~B}\left(\mathrm{mg} \cdot \mathrm{L}^{-1}\right)$ & 0.04 & 0.27 & 0.21 \\
$\mathrm{~K}\left(\mathrm{mg} \cdot \mathrm{L}^{-1}\right)$ & 1.2 & 13 & 17 \\
Fe $\left(\mathrm{mg} \cdot \mathrm{L}^{-1}\right)$ & 0.56 & 0.22 & 0.30 \\
\hline
\end{tabular}

${ }^{\mathrm{z}}$ Average values of five samples for each group, respectively.

${ }^{\mathrm{y}}$ Water samples were collected from irrigation ponds or sprinkler outlets on golf courses.

$\mathrm{NH}_{4}=$ ammonium; $\mathrm{N}=$ nitrogen; $\mathrm{N} / \mathrm{A}=$ not available; $\mathrm{NO}_{3}=$ nitrate $; \mathrm{P}=$ phosphorus $; \mathrm{EC}=$ electrical conductivity; $\mathrm{Ca}=$ calcium; $\mathrm{Mg}$ = magnesium; $\mathrm{Na}=$ sodium; $\mathrm{Cl}=$ chlorine; $\mathrm{B}=$ boron; $\mathrm{K}=$ potassium; $\mathrm{Fe}=$ iron.

the $\mathrm{Cl}^{-}$selective electrode (Thermo Electron Co. Orion 9617BNWP; Thermo Fisher Scientific, Waltham, MA).

Soil sampling and analysis. At the same times and locations of KBG shoot collections, soil samples were collected. At each sample site, three cores were collected at 0 to $20 \mathrm{~cm}$ using a hand-held boring tool. Three cores at each site were combined for analysis. All soil samples were allowed to air dry and were then ground and screened to pass through a 10 -mesh (2-mm) sieve. Each soil sample was tested for soil EC and SAR.

Soil was analyzed using a saturated paste extract. The EC value was measured using an EC meter. The saturated paste extracts were transferred to auto-sampler tubes and analyzed for $\mathrm{Ca}, \mathrm{Mg}$, and $\mathrm{Na}$ concentrations using inductively coupled plasma atomic emission spectrophotometry. Sodium adsorption ratio was calculated as $\mathrm{SAR}=\mathrm{Na} /[(\mathrm{Ca}+\mathrm{Mg}) / 2]^{1 / 2}$.

\section{Statistical analysis}

Shoot mineral concentrations including $\mathrm{Na}, \mathrm{Ca}, \mathrm{Mg}, \mathrm{K}, \mathrm{Cl}, \mathrm{B}, \mathrm{S}, \mathrm{P}$, manganese, iron, zinc, cooper, and molybdenum were subjected to statistical analysis procedures to investigate the relationships between individual mineral ions and turf quality (SAS Institute, 2011).

Turf quality and mineral concentrations in the KBG shoots were tested by analysis of variance, with different irrigation group as the treatment factor and individual golf courses as the block factor (Table 2) (SAS Institute, 2011). Comparison of the three different golf course groups was accomplished by the least significance difference method (Table 3). The Pearson correlation test was performed by Proc CORR to obtain Pearson statistic coefficients of individual minerals and its relationship with turf quality. Stepwise regression was conducted to determine whether any of the minerals accumulated in shoot tissues were related to turf quality ratings. Stepwise multiple regressions
Table 2. Analysis of variance of turf quality; kentucky bluegrass shoot $\mathrm{Na}, \mathrm{Ca}, \mathrm{Mg}, \mathrm{K}, \mathrm{Cl}$, $\mathrm{B}, \mathrm{S}, \mathrm{P}, \mathrm{Mn}, \mathrm{Fe}, \mathrm{Zn}, \mathrm{Cu}$, and Mo content; shoot $\mathrm{K} / \mathrm{Na}$; soil electrical conductivity (EC); and soil sodium absorption ratio (SAR) with mean squares and significance levels.

\begin{tabular}{lcc}
\hline & \multicolumn{2}{c}{ Mean squares } \\
\cline { 2 - 3 } Parameters & Irrigation group & Block \\
\hline Turf quality & $3.0^{* *}$ & 0.51 \\
$\mathrm{Na}$ & $15.7 \times 10^{6 * * * *}$ & $0.9 \times 10^{6 *}$ \\
$\mathrm{Ca}$ & $7.7 \times 10^{6 * * * *}$ & $1.1 \times 10^{6 *}$ \\
$\mathrm{Mg}$ & $2.5 \times 10^{6 * * * *}$ & $1.7 \times 10^{6 * * *}$ \\
$\mathrm{~K}$ & $69 \times 10^{6 * * *}$ & $47 \times 10^{6 * * *}$ \\
$\mathrm{Cl}$ & $9.4 \times 10^{6 *}$ & $14.7 \times 10^{6 * *}$ \\
$\mathrm{~B}$ & $543^{* * * *}$ & 35 \\
$\mathrm{P}$ & $1.3 \times 10^{6}$ & $5.9 \times 10^{6 * * * *}$ \\
$\mathrm{~K} / \mathrm{Na}$ & $5737^{* * * *}$ & 17 \\
$\mathrm{~S}$ & $22 \times 10^{6 * * * *}$ & $0.43^{*}$ \\
$\mathrm{Fe}$ & $8.8 \times 10^{4 * *}$ & $4.5 \times 10^{4 *}$ \\
$\mathrm{Zn}$ & $325^{* *}$ & 1.0 \\
$\mathrm{Cu}$ & 2.59 & 3.59 \\
$\mathrm{Mn}$ & $12919^{* * *}$ & $8344 * *$ \\
$\mathrm{Mo}$ & 1.9 & 2.28 \\
$\mathrm{Soil} \mathrm{EC}$ & $5.3^{* *}$ & 1.0 \\
Soil SAR & $230^{* * *}$ & $69^{*}$ \\
\hline$* * * * * * * * * *$ Significant at & $P \leq 0.05,0.01$
\end{tabular}
0.001 , or 0.0001 , respectively.

$\mathrm{Na}=$ sodium $; \mathrm{Ca}=$ calcium $; \mathrm{Mg}=$ magnesium $; \mathrm{K}=$ potassium; $\mathrm{Cl}=$ chlorine; $\mathrm{B}=$ boron; $\mathrm{S}=$ sulfur; $\mathrm{P}=$ phosphorus; $\mathrm{Mn}=$ manganese $; \mathrm{Fe}=$ iron; $\mathrm{Zn}=$ zinc; $\mathrm{Cu}=$ copper; $\mathrm{Mo}=$ molybdenum.

were done by using turf quality as a response variable and 13 mineral concentrations plus $\mathrm{K} / \mathrm{Na}$ ratio as predictor variables, and significance was chosen at the probability level of 0.05 (SAS Institute, 2011). The relationship among shoot $\mathrm{Na}$ concentration, soil chemical properties, and turf quality also were determined using regression analysis described previously.

\section{Results and Discussion}

Turf quality. KBG at the surface water irrigation sites and the 10-year recycled water irrigation sites had similar turf quality ratings. The average KBG turf quality for the 
pioneer recycled water irrigation sites was lower than the surface water irrigation group and the 10-year recycled water irrigation group (Table 3 ). There was a linear relationship $\left(R^{2}=0.65, P \leq 0.05\right)$ between turf quality and $\mathrm{Na}$ concentration in the shoots (Fig. 1).

Specific ion concentration in $K B G$ shoots under recycled water irrigation. Sodium accumulation in the shoots was found in all recycled water irrigated courses (Table 3 ). Recycled water irrigation increased $\mathrm{Na}$ concentration in shoots of KBG by 4.3 times in the 10-year recycled water irrigation group and 9.9 times in the pioneer recycled water irrigation group (Table 3). Mean KBG shoots $\mathrm{Na}^{+}$concentration in the 10 -year group was $1427 \mathrm{mg} \cdot \mathrm{kg}^{-1}$, ranging from 921 to 2281 $\mathrm{mg} \cdot \mathrm{kg}^{-1}$. In contrast, there were four sites with $\mathrm{Na}^{+}$concentrations greater than 4000 $\mathrm{mg} \cdot \mathrm{kg}^{-1}$ in the pioneer recycled water irrigation courses. The overall mean from the pioneer group (3256 mg. $\mathrm{kg}^{-1}$ ) was 2.28 times greater than the mean from the 10-year recycled water irrigation group. KBG shoot samples from surface water irrigated sites contained a significantly lower $\mathrm{Na}^{+}$concentration than both recycled water irrigation groups, with a mean value of $329 \mathrm{mg} \cdot \mathrm{kg}^{-1}$.

Potassium stood out as the greatest nutrient mineral in shoot tissue, ranging from 11,780 to $26,804 \mathrm{mg} \cdot \mathrm{kg}^{-1}$ in all samples. Mean K concentration was $22,642 \mathrm{mg} \cdot \mathrm{kg}^{-1}$ in KBG samples of the 10-year recycled water irrigation group, which is statistically the same as surface water irrigated sites (20,637 mg. $\mathrm{kg}^{-1}$ ) (Table 3). Although KBG shoot $\mathrm{K}^{+}$concentration varied between holes from recycled water irrigation courses, mean $\mathrm{KBG}$ shoot $\mathrm{K}^{+}$concentration in the pioneer group was $17,372 \mathrm{mg} \cdot \mathrm{kg}^{-1}, 16 \%$ lower than the surface water irrigation group $(20,637$ $\left.\mathrm{mg} \cdot \mathrm{kg}^{-1}\right)$. Interestingly, the three lowest shoot $\mathrm{K}^{+}$concentrations and the three greatest shoot $\mathrm{Na}^{+}$concentrations were found at one golf course within the pioneer group.

$\mathrm{KBG}$ shoot $\mathrm{K} / \mathrm{Na}$ ratio differed among the three different irrigation groups (Table 3 ). The greatest $\mathrm{K} / \mathrm{Na}$ ratio was observed in the surface water irrigation group (64.3). The mean $\mathrm{KBG}$ shoot $\mathrm{K} / \mathrm{Na}$ dropped to 16.6 for the 10-year recycled water irrigation group that was significantly higher than the $\mathrm{K} / \mathrm{Na}$ ratio of the pioneer group (6.3).

Chloride concentration increased under recycled water irrigation. Shoot $\mathrm{Cl}$ concentration in the 10-year group ranged from 5205 to $12,938 \mathrm{mg} \cdot \mathrm{kg}^{-1}$ with an overall mean 7545 $\mathrm{mg} \cdot \mathrm{kg}^{-1}$, which was similar to the pioneer group with an overall mean $\mathrm{Cl}$ concentration of $6734 \mathrm{mg} \cdot \mathrm{kg}^{-1}$. When compared with surface water irrigated $\mathrm{KBG}, \mathrm{Cl}$ concentration increased by 1.5 and 1.3 times, for the 10 year and pioneer recycled water irrigation groups, respectively (Table 3 ).

The average $\mathrm{B}$ concentration in KBG shoots was 5.9 and $7.7 \mathrm{mg} \cdot \mathrm{kg}^{-1}$ from surface water irrigated group and in the 10-year recycled water irrigation group with no difference between them. In the pioneer group, KBG shoot B concentration (with a mean of

Table 3. Mean separation of turf quality, soil electrical conductivity (EC), soil sodium absorption ratio (SAR), and shoot mineral concentration of kentucky bluegrass grown on golf course roughs under different years of recycled water irrigation.

\begin{tabular}{lccc}
\hline Parameter & Surface water & $\begin{array}{c}\text { 10-yr recycled } \\
\text { water irrigation }\end{array}$ & $\begin{array}{c}\text { Pioneer recycled } \\
\text { water irrigation }(18-26 \text { yr })\end{array}$ \\
\hline Turf quality & $8.2 \mathrm{a}^{\mathrm{y}}$ & $7.8 \mathrm{a}$ & $7.1 \mathrm{~b}$ \\
$\mathrm{Na}$ & $329 \mathrm{c}$ & $1,427 \mathrm{~b}$ & $3,256 \mathrm{a}$ \\
$\mathrm{Ca}$ & $3,856 \mathrm{~b}$ & $3,426 \mathrm{~b}$ & $5,159 \mathrm{a}$ \\
$\mathrm{Mg}$ & $1,874 \mathrm{~b}$ & $2,725 \mathrm{a}$ & $1,780 \mathrm{~b}$ \\
$\mathrm{~K}$ & $20,637 \mathrm{a}$ & $22,642 \mathrm{a}$ & $17,372 \mathrm{~b}$ \\
$\mathrm{Cl}$ & $5,027 \mathrm{~b}$ & $7,545 \mathrm{a}$ & $6,734 \mathrm{a}$ \\
$\mathrm{B}$ & $5.9 \mathrm{~b}$ & $7.7 \mathrm{~b}$ & $20.8 \mathrm{a}$ \\
$\mathrm{P}$ & 4,513 & 3,864 & 4,517 \\
$\mathrm{~K} / \mathrm{Na}$ & $64.3 \mathrm{a}$ & $16.6 \mathrm{~b}$ & $6.3 \mathrm{c}$ \\
$\mathrm{S}$ & $1,996 \mathrm{~b}$ & $1,285 \mathrm{c}$ & $4,517 \mathrm{a}$ \\
$\mathrm{Fe}$ & $282.4 \mathrm{a}$ & $105.4 \mathrm{~b}$ & $270.8 \mathrm{a}$ \\
$\mathrm{Zn}$ & $35.99 \mathrm{a}$ & $25.29 \mathrm{~b}$ & $36.31 \mathrm{a}$ \\
$\mathrm{Cu}$ & 5.28 & 5.4 & 4.4 \\
$\mathrm{Mn}$ & $51.8 \mathrm{~b}$ & $33.5 \mathrm{~b}$ & $104.6 \mathrm{a}$ \\
$\mathrm{Mo}$ & 2.84 & 2.24 & 3.1 \\
Soil EC & $1.0 \mathrm{~b}$ & $1.2 \mathrm{~b}$ & $2.4 \mathrm{a}$ \\
Soil SAR & $1.1 \mathrm{c}$ & $3.5 \mathrm{~b}$ & $9.4 \mathrm{a}$ \\
\hline
\end{tabular}

${ }^{\mathrm{z}}$ Units are $\mathrm{mg} \cdot \mathrm{kg}^{-1}$ except for $\mathrm{K} / \mathrm{Na}$ ratio, soil $\mathrm{EC}\left(\mathrm{dS} \cdot \mathrm{m}^{-1}\right)$, soil SAR, and turf quality $(1-9$ scale, $9=$ best $)$. ${ }^{\mathrm{y}}$ Means within a row followed by the same letter are not significantly different based on least significant difference (0.05); no letters shown indicate not statistically significant.

$\mathrm{Na}=$ sodium $; \mathrm{Ca}=$ calcium; $\mathrm{Mg}$ = magnesium $; \mathrm{K}=$ potassium $\mathrm{Cl}=$ chlorine $; \mathrm{B}=$ boron; $\mathrm{P}=$ phosphorus; $\mathrm{S}=$ sulfur; $\mathrm{Fe}=$ iron; $\mathrm{Zn}=$ zinc $; \mathrm{Cu}=$ copper; $\mathrm{Mn}=$ manganese; $\mathrm{Mo}=$ molybdenum.

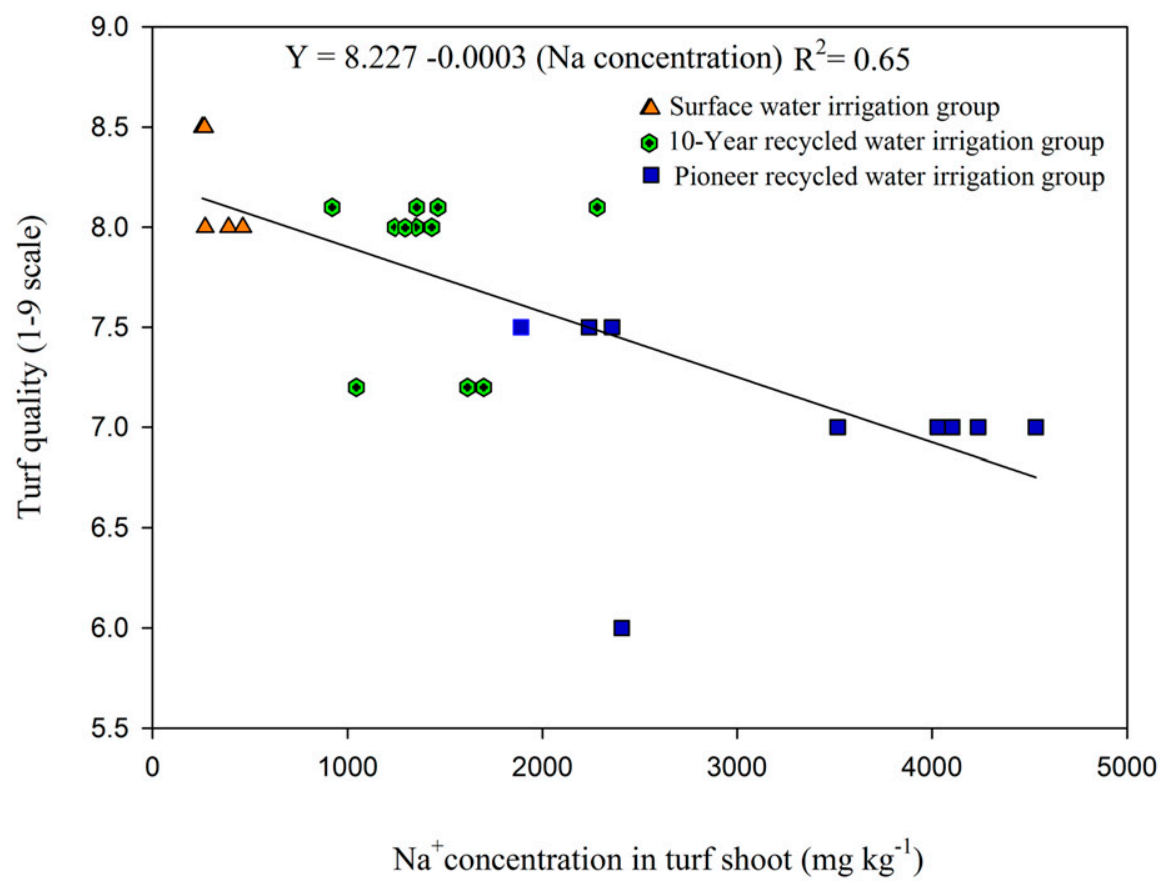

Fig. 1. Linear regression analysis of shoot $\mathrm{Na}$ concentration to turf quality under three irrigation regiments. $\mathrm{Na}=$ sodium

$20.8 \mathrm{mg} \cdot \mathrm{kg}^{-1}$ ) was 3.5 times greater than the surface water irrigation group (Table 3). Although the critical values for B deficiency and toxicity levels in KBG have not been established, the reported $\mathrm{B}$ concentration in KBG shoots ranges from 7.5 (Butler and Hodges, 1967) to $16 \mathrm{mg} \cdot \mathrm{kg}^{-1}$ (Waddington and Zimmerman (1972). Marschner (1995) reports an optimal boron concentration range for grasses of 5 to $10 \mathrm{mg} \cdot \mathrm{kg}^{-1}$.

Turf quality and the relationship with shoot $\mathrm{Na}^{+}$and $\mathrm{K} / \mathrm{Na}$ ratio. Under recycled water irrigation, $\mathrm{KBG}$ shoots accumulated $\mathrm{Na}$, along with $\mathrm{Cl}$ and $\mathrm{B}$. Although three elements $(\mathrm{Na}, \mathrm{B}, \mathrm{S})$ and $\mathrm{K} / \mathrm{Na}$ ratio showed greater correlation with turf quality, stepwise regression analysis revealed that, among all elements tested, the only mineral that significantly influenced on turf quality was $\mathrm{Na}\left(P<0.05\right.$ and $\left.R^{2}=0.65\right)$. Sodium posed negative effect $(r=-0.81)$ to turf quality with a high significance level $(P<$ 0.0001 ). The lowest turf quality ratings observed in the pioneer group coincided with its greatest $\mathrm{Na}$ concentration in $\mathrm{KBG}$ shoots in this group. The ratio of $\mathrm{K} / \mathrm{Na}$ had positive correlation with turf quality, which was likely due to the competition between $\mathrm{Na}$ and K (Table 4). Metabolic toxicity of $\mathrm{Na}^{+}$is partially a result of its ability to 
Table 4. Pearson correlation coefficients among 13 shoot mineral concentrations, K/Na ratio, and turf quality of kentucky bluegrass.

\begin{tabular}{|c|c|c|c|c|c|c|c|c|c|c|c|c|c|c|}
\hline & $\mathrm{Na}$ & $\mathrm{Ca}$ & $\mathrm{Mg}$ & $\mathrm{K}$ & $\mathrm{Cl}$ & $\mathrm{B}$ & $\mathrm{S}$ & $\mathrm{P}$ & $\mathrm{Fe}$ & $\mathrm{Mn}$ & $\mathrm{Zn}$ & $\mathrm{Cu}$ & Mo & $\mathrm{K} / \mathrm{Na}$ \\
\hline \multicolumn{15}{|l|}{$\mathrm{Na}$} \\
\hline $\mathrm{Ca}$ & 0.55 & & & & & & & & & & & & & \\
\hline $\mathrm{Mg}$ & -0.04 & -0.07 & & & & & & & & & & & & \\
\hline K & $-0.56 * *$ & $-0.43^{*}$ & -0.1 & & & & & & & & & & & \\
\hline $\mathrm{Cl}$ & 0.2 & -0.05 & $0.47^{*}$ & -0.11 & & & & & & & & & & \\
\hline B & $0.76 * * *$ & $0.66 * * *$ & -0.37 & -0.37 & -0.17 & & & & & & & & & \\
\hline S & $0.71 * * *$ & $0.56 * *$ & $-0.59 * *$ & -0.42 & -0.10 & $0.70 * * *$ & & & & & & & & \\
\hline $\mathrm{P}$ & -0.23 & 0.04 & $-0.58 * *$ & $0.63 * *$ & -0.13 & 0.05 & 0.22 & & & & & & & \\
\hline $\mathrm{Fe}$ & 0.22 & 0.31 & -0.36 & -0.10 & -0.08 & 0.11 & 0.46 & 0.34 & & & & & & \\
\hline $\mathrm{Mn}$ & $0.46^{*}$ & 0.11 & $-0.66 * * *$ & -0.16 & -0.31 & $0.56^{* *}$ & $0.76 * * *$ & 0.14 & 0.25 & & & & & \\
\hline $\mathrm{Zn}$ & 0.04 & 0.32 & $-0.58 * *$ & 0.37 & -0.15 & 0.22 & 0.46 & $0.88 * * *$ & $0.57 * *$ & 0.20 & & & & \\
\hline $\mathrm{Cu}$ & -0.39 & -0.27 & 0.004 & $0.70 * * *$ & 0.05 & -0.35 & -0.33 & 0.50 & 0.06 & -0.24 & 0.30 & & & \\
\hline Mo & -0.1 & -0.02 & -0.45 & 0.21 & -0.41 & 0.11 & 0.30 & 0.42 & -0.19 & 0.50 & 0.46 & 0.07 & & \\
\hline $\mathrm{K} / \mathrm{Na}$ & $-0.75 * * *$ & -0.02 & -0.15 & 0.23 & -0.31 & -0.49 & -0.35 & 0.22 & 0.26 & -0.21 & 0.30 & 0.25 & 0.14 & 1 \\
\hline Turf quality & $-0.81 * * *$ & -0.36 & 0.15 & 0.51 & -0.06 & $-0.71 * * *$ & $-0.66^{* *}$ & 0.11 & -0.20 & -0.44 & 0.04 & 0.46 & 0.14 & $0.65 * * *$ \\
\hline
\end{tabular}

** Significant at $P \leq 0.05 ; * * *$ significant at $P \leq 0.01$.

$\mathrm{K}=$ potassium $; \mathrm{Na}=$ sodium $; \mathrm{Ca}=$ calcium $; \mathrm{Mg}=$ magnesium $; \mathrm{Cl}=$ chlorine $; \mathrm{B}=$ boron $; \mathrm{S}=$ sulfur $\mathrm{P}=$ phosphorus $; \mathrm{Fe}=$ iron $; \mathrm{Mn}=$ manganese $\mathrm{Zn}=\mathrm{zinc} ; \mathrm{Cu}=$ copper; Mo = molybdenum.

compete with $\mathrm{K}^{+}$for binding sites essential for cellular function. More than 50 enzymes in plants are activated by $\mathrm{K}^{+}$, but $\mathrm{Na}^{+}$cannot substitute in this role. Thus, high levels of $\mathrm{Na}^{+}$or low $\mathrm{K} / \mathrm{Na}$ ratio can disrupt various enzyme processes in the cytoplasm. The decline in KBG turf quality might be associated with the high concentration of $\mathrm{Na}$ competing with $\mathrm{K}$ for enzyme binding sites. Pearson correlation analysis indicated that shoot $\mathrm{Na}$ concentration negatively associated with $\mathrm{K}$ and $\mathrm{K} / \mathrm{Na}$ ratio but positively correlated with $\mathrm{B}$ and $\mathrm{S}$ shoot concentrations (Table 4), which lead to the positive correlation between turf quality and shoot $\mathrm{K}$ concentration but negative correlation between turf quality and shoot $\mathrm{B}(r=-0.71$, $P \leq 0.001)$ and $\mathrm{S}(r=-0.66, P \leq 0.001)$ concentrations.

Reduction in $\mathrm{K} / \mathrm{Na}$ ratio under recycled water irrigation was accompanied with turf quality decline (Tables 3 and 4). This finding was in agreement with previous published research (Qian et al., 2001, 2004; Wang et al., 2013). The same findings have also been highlighted in other papers on both cool season and warm season turfgrasses (Krishnan and Brown, 2009; Marcum et al., 1998).

Results from this study showed that as $\mathrm{Na}$ accumulated in the KBG exceeding $3500 \mathrm{mg} \cdot \mathrm{kg}^{-1}$, turf quality decreased to a rating of 7.2 (Fig. 1). Carrow (2001) explained two physiological functions regarding how $\mathrm{Na}$ influences turfgrass growth: the first is causing ion toxicity to plant tissue and the other is causing an ion imbalance. $\mathrm{KBG}$ in the pioneer golf courses had an average Na level of 3256 $\mathrm{mg} \cdot \mathrm{kg}^{-1}$ in the shoots and displayed a lower turf quality. 'Brilliant' KBG had shoot $\mathrm{Na}$ of $4289 \mathrm{mg} \cdot \mathrm{kg}^{-1}$ when treated with saline irrigation water at $3 \mathrm{dS} \cdot \mathrm{m}^{-1}$ and mowed at $50 \mathrm{~mm}$ height in a greenhouse study (Wang et al., 2013). This level of shoot Na concentration was represented for samples collected at one of the pioneer recycled water irrigation golf courses in this study.

Soil chemical property link to KBG shoot $\mathrm{Na}$ accumulation and turf quality. Soil (0-20 $\mathrm{cm})$ at the surface water irrigation sites and

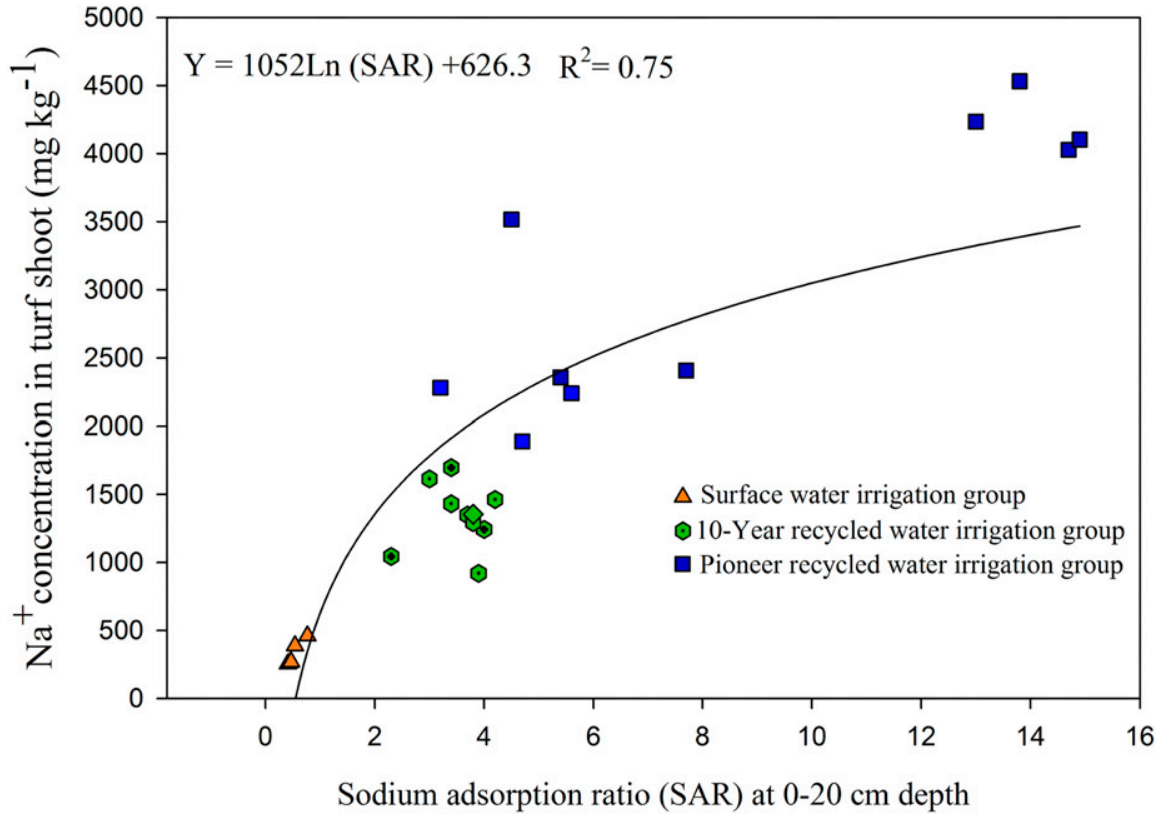

Fig. 2. Logarithmic regression analysis of soil SAR $(0-20 \mathrm{~cm})$ to corresponding shoot Na concentration of kentucky bluegrass under three different irrigation regiments. $\mathrm{Na}=$ sodium; $\mathrm{SAR}=$ sodium absorption ratio.

the 10 -year recycled water irrigation sites had similar soil EC at 1.0 and $1.2 \mathrm{dS} \cdot \mathrm{m}^{-1}$, respectively (Table 3 ). Soil EC for the pioneer recycled water irrigation sites was $2.4 \mathrm{dS} \cdot \mathrm{m}^{-1}$, which was significantly greater than the surface water irrigation sites and the 10-year recycled water irrigation group. There was a weak but linear relationship $\left(R^{2}=-0.30, P \leq\right.$ $0.05)$ between turf quality and soil EC. Several studies have investigated changes in EC with recycled water or other marginally saline water irrigation. Mancino and Pepper (1992) found that, after 3.2 years of use, recycled water increased soil EC by 0.2 $\mathrm{dS} \cdot \mathrm{m}^{-1}$. Lockett et al. (2008) reported that after transitioning from fresh water to recycled water irrigation for 1.5 to 3.7 years, soil salinity increased $27 \%$ to $32 \%$. Chen et al. (2013) observed 19.2\% increase in soil salinity in urban green land irrigated with recycled water for 10 years in Beijing, China.
At an urban park irrigated with groundwater of $\approx 1.1 \mathrm{dS} \cdot \mathrm{m}^{-1}$ salinity for 49 years, Ganjegunte et al. (2017) reported an average soil EC of $8.7 \mathrm{dS} \cdot \mathrm{m}^{-1}$. However, the measured soil EC peaks were as high as $43 \mathrm{dS} \cdot \mathrm{m}^{-1}$. The authors indicated that uneven distribution of irrigation water combined with a lack of drainage system likely caused the uneven distribution of soil EC.

Soil SAR in the pioneer group was 9.4, greater than the 10-year group, with an average SAR value of 3.5. Soil from the surface water irrigation site had the lowest average SAR value of 1.1 (Table 3 ). There was a significant linear relationship $\left(R^{2}=-0.49, P \leq 0.0001\right)$ between turf quality and soil SAR. As discussed previously, shoot $\mathrm{Na}$ concentration linearly influenced turf quality with $R^{2}$ value of 0.65 (Fig. 1). The surface soil SAR showed a logarithm nonlinear relationship to shoot $\mathrm{Na}$ concentration $\left(R^{2}=0.75, P \leq 0.001\right)$ (Fig. 2). 
Soil SAR values of both recycled water irrigation groups were greater than the surface water irrigation group. KBG with lower turf quality (courses in the pioneer group) had greater shoot $\mathrm{Na}$ concentration and greater SAR in the topsoil $(0-20 \mathrm{~cm})$.

\section{Conclusions}

KBG shoot Na concentration in the pioneer recycled water irrigation group was 1.3 and 8.9 times greater than that in the 10 -year recycled water and surface water irrigation groups, respectively. Shoot Na concentration in the 10-year recycled water irrigation group was 3.3 times greater than that in the surface water irrigation group. Based on stepwise regression analyses, $\mathrm{Na}$ accumulation in KBG shoots was the major factor leading to negative influences on turf quality. In addition, soil SAR in the pioneer group was greater than that of the 10-year group. Soil from the surface water irrigation site had the lowest average SAR value. A lower turf quality was associated with greater $\mathrm{Na}$ concentration in the shoots and greater SAR in the topsoil $(0-20 \mathrm{~cm})$ under recycled water irrigation. On the basis of our findings, shoot $\mathrm{Na}$ concentration is the best predictive variable to explain turf quality under recycled water irrigation in this study. Therefore, it is reasonable to suggest that water treatment and management practices that can reduce soil SAR and KBG Na concentration in the shoots would improve turf quality and plant health under recycled water irrigation.

\section{Literature Cited}

Alshammary, S., Y. Qian, and S.J. Wallner. 2004. Growth response of four turfgrass species to salinity. Agr. Water Mgt. 66:97-111.
Butler, J.D. and T.K. Hodges. 1967. Mineral composition of turfgrass. HortScience 2:62-63.

Carrow, R.N. 2001. Turfgrass soil fertility and chemical problems: Assessment and management. John Wiley \& Sons, Hoboken, NJ.

Chen, W.P., S.D. Lu, N. Pan, and W.T. Jiao. 2013. Impacts of long-term reclaimed water irrigation on soil salinity accumulation in urban green land in Beijing. Water Resour. Res. 49:7401-7410.

Clifford, W.A. and N.J. Doesken. 2009. Detecting trends in evapotranspiration in Colorado. Colorado Water Institute. Completion Report No. 217.

Golf Course Superintendents Association of America (GCSAA). 2009. Golf Course Environmental Profile Volume II, Water Use and Conservation Practices on U.S. Golf Courses. 17 June 2018 $<$ https://www.gcsaa.org/Uploadedfiles/Environment/ Environmental-Profile/Water/Golf-CourseEnvironmental-Profile-Water-Use-and-ConservationReport.pdf>.

Ganjegunte, G.K., J.A. Clark, R. Sallenave, E. Sevostianova, M. Serena, G. Alvarez, and B. Leinauer. 2017. Soil salinity of an urban park after long-term irrigation with saline ground water. Agron. J. 109:3011-3018.

Gorham, J., R.G. Wyn Jones, and E. McDonnell. 1985. Some mechanisms of salt tolerance in crop plants. Plant Soil 89:15-40.

Krishnan, S. and R.N. Brown. 2009. $\mathrm{Na}^{+}$and $\mathrm{K}$ accumulation in perennial ryegrass and red fescue accessions differing in salt tolerance. Intl. Turfgrass Soc. Res. J. 11:817-827.

Lockett, A.M., D.A. Devitt, and R.L. Morris. 2008. Impact of reuse water on golf course soil and turfgrass parameters monitored over a 4.5 -year period. HortScience 43:2210-2218

Mancino, C.F. and I.L. Pepper. 1992. Irrigation of turfgrass with secondary sewage effluent: Soil quality. Agron. J. 84:650-654.

Marcum, K.B. and C.L. Murdoch. 1990. Growth response, ion relations and osmotic adaptations of eleven $\mathrm{C} 4$ turfgrasses to salinity. Agron. J. 82:892-896.

Marcum, K.B., S.J. Anderson, and M.C. Engelke. 1998. Salt gland ion secretion: A salinity tolerance mechanism among five Zoysiagrass species. Crop Sci. 38:806-810.

Marschner, H. 1995. Mineral nutrition of higher plants. 2nd ed. Academic Press, London.

Maupin, M.A., J.F. Kenny, S.S. Hutson, J.K. Lovelace, N.L. Barber, and K.S. Linsey. 2014. Estimated use of water in the United States in 2010: U.S. Geological Survey Circular 1405 , 56 p. 3 Sept. $2018 .<$ https://doi.org/10.3133/ cir1405>.

Morris, K. and R. Shearman. 2010. A guide to NTEP Turfgrass Ratings. Online. Turf Evaluation Guidelines. 17 June 2017. <http://www. ntep.org/pdf/ratings.pdf $>$.

Qian, Y.L. and B. Mecham. 2005. Long-term effects of recycled wastewater irrigation on soil chemical properties on golf course fairways. Agron. J. 97:717-721.

Qian, Y.L., S. Wilhelm, and K.B. Marcum. 2001. Comparative responses of two Kentucky bluegrass cultivars to salinity stress. Crop Sci. 41:1895-1900.

Qian, Y.L., R.F. Follett, S. Wilhelm, A.J. Koski, and M.A. Shahba. 2004. Carbon isotope discrimination of three Kentucky bluegrass cultivars with contrasting salinity tolerance. Agron. J. 96:571-575.

Richards, L.A. 1954. Diagnosis and improvement of saline and alkali soils. Handb. 60. U.S. Soil Salinity Lab., Riverside, CA.

SAS Institute. 2011. SAS/STAT user's guide. SAS Inst., Cary, NC.

Waddington, D.V. and T.L. Zimmerman. 1972. Growth and chemical composition of eight grasses grown under high water table conditions. Commun. Soil Sci. Plant Anal. 3:329337.

Wang, J.Z., J.M. Fu, S.J. Wilhelm, and Y.L. Qian. 2013. Performance and physiological process of brilliant Kentucky bluegrass (Poa Pratensis L.) in response to salinity and mowing management. Intl. Turfgrass Soc. Res. J. 12:491495. 